\title{
Does Politics Crowd out Professional Competence? The Organization of Ministerial Advice in Denmark and Sweden
}

West European Politics.

DOI: 10.1080/01402382.2016.1176368

\author{
Peter Munk Christiansen \\ Department of Political Science \\ Aarhus University, Denmark \\ pmc@ps.au.dk
}

\section{Birgitta Niklasson \\ Department of Political Science \\ Gothenburg University, Sweden \\ birgitta.niklasson@pol.gu.se \\ Patrik Öhberg \\ Gothenburg University, Sweden \\ patrik.ohberg@pol.gu.se}

\begin{abstract}
:
The use of politically appointed ministerial advisors has increased noticeably in many Western countries, but we know little about how this development has affected the civil servants recruited on merit. The article asks whether political appointees accentuate or blur the line between politics and administration. Do political appointees take over politicaltactical advice and leave policy advice to the permanent civil service, or do they cause permanent civil servants to be even more influenced by political considerations? And do political appointees make it easier or more difficult for the permanent civil service to be politically responsive? A Most Similar Systems Design comparison of Denmark and Sweden allows an assessment of the effects of political appointees, and it is found that a large number of political appointees decreases functional politicisation of the permanent civil service; that functional politicisation tends to crowd out tasks related to more classic policy advice; and that functional politicisation increases political responsiveness.
\end{abstract}


The first method for estimating the intelligence of a ruler is to look at the men he has around him

- Niccolò Machiavelli, The Prince

Sovereigns and governments have always been dependent on advisers whom they trust. In the 1600s, European sovereigns surrounded themselves with their own councils of nobles and priests (Schück 1988; Lyngby et al. 2010). In the 1900s, most of these regents had been replaced by elected politicians who were advised and supported by neutral and professional Weberian bureaucrats (Silberman 1993). Today, Weberian merit-recruited civil servants constitute the backbone of Western bureaucracies.

They have, however, been met with scepticism. Woodrow Wilson and Max Weber, the early fathers of the study of modern bureaucracy, were proponents of merit-recruited civil servants and the whole idea of modern bureaucracy, but they were also wary of the politicalbureaucratic nexus. Weber (1958) feared the power of professional bureaucrats vis-à-vis dilettante politicians, and Wilson (1887) feared that bureaucrats would develop into a class of their own - at great distance from the rest of society.

A common response to the scepticism towards bureaucracy - at least in the AngloSaxon and Scandinavian countries - has been to recruit political advisers (Dahlström 2009). They are recruited on political merits and only remain in office for as long as their ministers do. Political advice can be organized in many different ways (OECD 2011; Eichbaum \& Shaw 2008; 2010; Wilson \& Barker 2003) and the choice of organization deserves careful consideration. Political advice serves potentially contradictory needs: it must be loyal to the political leadership and to the existing legislation, it must be carefully thought through, but also speedy and timely, and in communication it must be loyal to today's political principals and yet loyal to the truth. The organization of political advice thus implies various dilemmas, particularly in these times of mediatized and rushed political processes and complex political issues (Maley, 2000; Peters et al. 2000; Foster, 2001; Christiansen \& Togeby, 2006a; Hart \& Wille, 2006; OECD, 2011).

The literature has different views on the effect of political advisers. Since meritrecruited bureaucrats are still the backbone of Western bureaucracy, it is particularly important to know how political advisers affect the traditional civil service. Critics of the recruitment of political advisers have pointed to negative effects on the quality of government (Rothstein \& Theorell, 2012) such as corruption and inefficiency (Peters \& Pierre, 2004a; Lewis, 2007; 2008; Dahlström et al. 2011; Gallo \& Lewis, 2012). According to Rothstein and Theorell (2012), corruption compromises impartiality and quality of government. However, these studies address political recruitment broadly rather than recruitment of ministerial advisers specifically. Closer to our target group, we also find scepticism towards political advisers: Richard Mulgan (2007) and Peter Ehn et al. (2003: 440) point to the danger that political advisers transmit their partisan behaviour to the classic civil service. Other scholars like Chris Eichbaum and Richard Shaw (2005) and Hans-Ulrich Derlien (2003) emphasize positive or neutral effects of political advisers on the classic civil service.

Our research question is whether political advisers clear up or blur the line between politics and administration. More specifically we ask two questions: Do political advisers take over political-tactical advice and leave technical policy advice to the permanent civil 
service, or do political advisers cause permanent civil servants to be even more influenced by political considerations? And do political advisers make it easier or more difficult for the permanent civil service to be politically responsive? We contribute with a new approach to these questions: a Most Similar Systems Design (MSSD) comparison of Denmark and Sweden allows us to isolate the effects of political advisers. Data are generated from a survey of high-ranking civil servants in Denmark and Sweden with 282 Danish and 393 Swedish responses. We proceed as follows. First, we discuss the phenomenon of politicisation and develop hypotheses about the relationship between the advent of political advisers and politicisation. Second, we present our research design and data and argue that our research design is suitable for increasing our understanding of politicisation of the civil service in general. Third, we conduct the analyses and discuss our results.

\section{Theory and hypotheses}

\section{Politicisation}

Politicisation - a core concept in theory and analysis on ministerial advice - may occur in relation to the recruitment of civil service personnel, including political advisers, and in relation to the activities in which the civil service engages (Mulgan 2007; Hustedt \& Salomonsen 2014).

Politicisation through recruitment occurs in two ways. One is when political criteria fully or partially - and openly - replace merit-based criteria in the selection, promotion, rewarding and disciplining of public servants (see. Mayntz \& Derlien, 1989; Peters \& Pierre, 2004a; Lewis, 2008; Rouban, 2012; Christensen et al. 2014). This is when top civil servants are hired based on political criteria, which is the case in a few countries, and when ministers hire political advisers based on political criteria, which, to our knowledge, happens in all Western countries. This is sometimes referred to as formal politicisation (Hustedt \& Salomonsen, 2014). In the following, when we refer to political appointees we mean politically recruited civil servants who hold administrative responsibilities, while we use the generic term political advisers to cover politically recruited personnel with only advisory roles.

The other way politicisation occurs through recruitment is if merit recruitment is fully or partially replaced by political criteria, but covertly and in violation of the merit criterion. This malpractice is shown to have strong negative effects on the quality of government (Dahlström et al. 2011). In our analysis, we use the first example as our independent variable.

Politicisation may also be related to civil service activities in two ways. Functional politicisation occurs when civil servants perform tasks that go beyond bringing neutral expertise into the political and administrative processes (Hustedt \& Salomonsen, 2014). In Mayntz and Derlien's wording, functional politicisation is about the "power aspects" related to "policy development and departmental management generally" (1989: 401). In this sense, functional politicisation occurs when we move beyond the state when "civil servants bring neutral expertise ... while politicians bring political sensitivity" (Aberbach et al. 1981: 6). Goetz (1997) talks about political craft as a necessary qualification for a top civil service position and he defines it (in the German context) as "... the ability to assess the likely political implications and ramifications of policy proposals; to consider a specific issue within the broader context of the government's programme; to anticipate, ... influence or 
even manipulate the reactions of other actors in the policy-making process ... and to design processes that maximize the chances for the realization of ministers' substantive objectives" Goetz 1997: 754). In short, functional politicisation implies that the civil service engages in policy formation and all the activities that are involved in coalition building and conflict reduction, i.e. negotiations with interest groups and political parties, and handling relations to other public authorities, the media, and the public. The other variant, administrative politicisation, coined by Eichbaum and Shaw (2008: 342), refers to the effect on the permanent civil service of political advisers' activities, for instance when they interfere in the communication between ministers and civil servants. We use functional politicisation as our dependent variable. Our basic interest is to study whether politicised recruitment causes change in functional politicisation.

To get closer to the world of ministers, advisers, and civil servants, we distinguish between policy advice and political-tactical advice (cf. Mayntz \& Derlien, 1989). By policy advice we mean the substantial aspects of public policies: what are the alternative means available in the pursuit of specific political goals? What are their consequences in terms of benefits and costs? How can public policies be better targeted? How can they be better implemented? How do we run the government machinery better and more efficiently etc.? Policy advice comes close to Aberbach et al.'s (1981) neutral expertise. Arguably, advice on such issues falls within the frame of the Weberian civil service role and therefore should not be considered an example of functional politicisation. However, it must be delivered in ways that do not conflict with free and frank advice.

Political-tactical advice concerns the minister's relation to parliament, political parties, interest groups, and the general public: how can a minister push a policy through and take credit for it (Mayntz \& Derlien, 1989; Christensen et al. 2014)? How is understanding for a proposal established in the minister's party? How is a majority established in parliament? How can alliances with interest groups be built or opponent interest groups overcome? And how can the minister appear like a winner - or less like a loser - in the media? In short, political-tactical advice is about policy formation and about handling the political process. A civil service that provides this kind of advice is, in our definition, functionally politicised. Political-tactical advice comes close to Aberbach et al.'s (1981) political sensitivity.

As noted by Mayntz and Derlien (1989: 384-385), even the classic Prussian civil service was functionally politicised in the sense that it supported the established political order. The Weberian conception of a neutral civil service was not a description of the Prussian/German bureaucracy but a theoretical construct, as Weber (1958) was well aware that the distinction between politics and administration was analytical rather than empirical (see also Svara, 1999; 2001). Nevertheless, functional politicisation may be more or less pronounced, and the political functions of a bureaucracy may be distributed among a smaller or larger part of the civil service.

\section{The effects of politicised recruitment on functional politicisation}

Delegation is a necessity of modern administration. Political principals must delegate many decisions to agents to keep the government machinery going. They must even delegate the provision of political advice to agents (Damgaard, 2004). This raises the question of control: How can political principals - ministers - make sure that their political priorities are heard, 
become effective and are implemented, and that they receive the right advice in this endeavour?

For many years, the main answer to this question was that a merit-recruited civil service was the best way to secure impartial, legitimate, and legal administration, at least in a North European context. The North European tradition rests on the premise that since top civil servants have a permanent employment contract they will be careful to play their advisory role in a balanced way: "The fact that public servants must be ready to offer (and be seen to offer) the same degree of loyalty to an alternative government does impose curbs on the degree of partisan support and commitment that public servants can show the government of the day" (Mulgan, 2008: 348). A reaction to the challenges of modern administration and politics has been to employ an increasing number of political advisers and in some cases also an increasing number of politically recruited top civil servants. The question is how this development affects the traditional merit bureaucracy.

One could argue that by meeting the demand for more political-tactical advice by recruiting political advisers, the merit-recruited civil service will be protected. Political advisers will handle political-tactical advice, and the civil service will be relieved to only do policy advice. Civil servants run a smaller risk of being drawn into the political game when political advisers help politicians "make sense of and negotiate the fluid contours of the political landscape" (Eichbaum \& Shaw, 2005: 24) and still, "expertise is not sacrificed on the altar of political responsiveness" Derlien (2003: 408).

More sceptical voices claim that there is a risk of spill-over from politicised recruitment to functional politicisation:

[p]oliticized appointment processes, ..., will encourage politicized actions on the part of public servants. In particular, politicized appointments will undermine the traditional political neutrality of career public servants and their capacity to give ministers advice that is 'free and frank' (Mulgan, 2007: 571).

With explicit reference to ministerial rank and file employees, Ehn et al. (2003: 440) find that

[i]t is reasonable to assume that working in a strongly politicized ministerial environment, with proximity to the political decision-makers, contributed to strengthening the position of the political role model among the assistant undersecretaries.

It is thus appropriate to be wary of how much politicised recruitment affects functional politicisation throughout the ministerial hierarchy (Overeem, 2005; Mulgan, 2008). Politicisation may spread to a large part of the bureaucracy because political-tactical advice is precious in a politicised, busy, and complicated environment. This demand for politicaltactical advice may trigger a supply from other actors than those who are explicitly hired to offer it. In order to attract the attention of civil servants with power over positions, promotion, pay rises, lower ranking civil servants may start thinking about the political aspects of the ministry's tasks. They may, in other words, try to exchange political advice for future promotion, wage increase, or prestigious access to the minister. This implies a functional politicisation of the merit-recruited civil service in which part of the civil service faces possible clashes between technical policy considerations and "truth" on the one hand and political considerations and spin on the other (Peters \& Pierre, 2004a; Mulgan, 2007; Svara, 2001; Eichbaum \& Shaw, 2008; Lewis, 2008; Rouban, 2012; Christensen et al. 2014). 
If the magnitude of the demand for political-tactical advice is the same, we expect the meritrecruited civil servants to be less involved in political-tactical advice as the number of political advisers increases. Our first hypothesis is:

H1. The more political advisers, the less functional politicisation of the merit-recruited civil service.

The same relation may be hypothesized between the number of political appointees and functional politicisation. However, since we have insufficient variation on the number of political appointees we cannot test such a hypothesis empirically.

The next question is how functional politicisation affects the way merit-recruited civil servants handle the other part of their job, i.e. policy advice. Do top civil servants monopolize the supply of political-tactical advice in a system characterized by limited politicised recruitment of ministerial advisers, or does the political-tactical advice trickle down the hierarchical system via a mechanism like the one described above by Ehn et al. (2003)? Even if both positions find some theoretical support, we hypothesize that policy-related tasks tend to be crowded out in favour of political-tactical advice. With few political advisers, the pressure on top civil servants for political-tactical advice is high and they demand such advice from their organization. Lower-ranking bureaucrats are rewarded for policy advice as well as for political-tactical advice. As their attention to political-tactical advice increases, they will tend to focus less on policy advice and more on political-tactical advice. This brings us to our second hypothesis:

H2. Increasing functional politicisation crowds out merit-recruited civil servants'focus on policy-related tasks.

If our two first hypotheses are correct, systems with many political advisers have a clearer division of labour between the permanent civil servants, who are primarily occupied with policy advice, and political advisers, who are primarily occupied with political-tactical advice. No matter how functionally politicised the permanent civil service is, it must have some idea of what its minister wants. There may be a trade-off between political responsiveness on the one hand and neutrality and professional competence on the other (Rourke, 1992; Aberbach \& Rockman, 1994: 465), but civil servants work in a politically guided organization (Christensen, 2006), and even civil servants with few political-tactical assignments must know the political direction of the ministry in order to be receptive to the political messages.

In systems with few political advisers, the permanent civil service is more deeply involved in political-tactical advice, and the division of labour between political advisers and civil servants is less clear. This implies that the permanent civil service in the latter system has more experience with assessing the minister's wishes and directives. Further on, since they have to manoeuvre in more complicated waters, they are more aware of the institutional rules for their job and more aware of the limits of role as advisers compared to civil service systems with a clearer division of labour between policy advice and political-tactical advice. Our third and fourth hypotheses are thus:

H3. The more political advisers, the more difficult it is for the permanent civil service to read their minister's preferences 
H4. The more political advisers, the more uncertain the permanent civil service is about the limits of the role as adviser

\section{Research design and data}

Changes in the organization of political advice occur gradually, and this makes it difficult to tease out the marginal effects of the increase in the number of political advisers from the effects of other developments. To overcome this problem, we conduct a Most Similar Systems Design (MSSD) study of Denmark and Sweden.

Denmark and Sweden are neighbouring Scandinavian countries with universal welfare states and large public sectors. Both countries have comparatively efficient bureaucracies, and corruption levels are among the lowest in the world (Transparency International, 2012). They are small unitary states with parliamentary systems, a strong corporatist heritage, and influential Social Democratic parties. They have proportional, multi-party election systems and governments frequently consist of (minority) coalitions.

There are also some differences which may violate the MSSD design: Denmark has a system of ministerial governance, whereas the Swedish system rests on a collectively responsible government. In practice, the two models are less different than it sounds (Lindbom 1997: 39, 63-64), and we do not believe this difference to be of major importance for our purpose, because the distinction between policy advice and political-tactical advice is not dependent on whether ministerial responsibility is formally individual or collective. A second difference is that as the main rule the Swedish government agencies responsible for the implementation of policies are independent of the ministries, whereas the Danish government agencies are a part of the ministerial hierarchy. To deal with this potential problem, we only use indicators on policy advice and political-tactical advice, which we believe to be unrelated to the hierarchical status of the agencies. Sweden has a long and institutionalized tradition of setting up commissions to scrutinize public policies before bills are presented to parliament. The Danish tradition is more recent and less institutionalized. However, the Swedish system has changed significantly during recent decades. Commissions have been fewer, they operate within a shorter time horizon, and there is less emphasis on consensus building in the commissions (Petersson 2015). In short, the two systems have come closer to each other, and we do not believe this difference to have a significant impact on functional politicisation.

Both countries rely on a strong Weberian tradition of non-partisan merit recruitment but have slowly drifted apart since the 1960s. Denmark has been cautious about leaving the Weberian path. Only one exception to merit recruitment has been made: the so-called special advisers. Since the 2011 general election, there are at most 32 politically appointed advisers who are responsible for giving ministers political advice. Dahlström (2009: 9) thus finds that "[a]mong all countries in 2007, Denmark is the country with the lowest proportion of political advisers" (of 18 OECD countries) (see also Bischoff 2012; Kopecký et al. 2012). When special advisers were introduced in the 1990s they primarily advised ministers on media matters, but over time their tasks have expanded to other kinds of political advice. A 2013 government white paper describes their tasks as follows:

They cover media-related tasks, secretarial assistance to and services for the minister, the provision of advice to the minister in the form of general sparring, the drafting of 
speeches and accompanying the minister to meetings of different types as well as management of external contacts to parliament, stakeholder organisations and other ministries for the minister (White Paper 1537/2013: 181-182).

These advisers come and go with their minister; they are not a part of the organizational line, which means that they cannot have administrative responsibilities. Initially, they were mainly recruited from the media industry, but today also from public affairs companies and political party organizations. They are typically short on administrative and economic knowledge, but rich on political and media knowledge (de Visscher \& Salomonsen 2013). For this reason, they are often referred to as spin doctors in the media and in the public (White Paper 1537/2013).

For substantial political advice on policies and advice on the political process, Danish ministers also rely on advice from the departments' permanent heads (permanent state secretaries) and other top civil servants. They are recruited on formal merits and a documented ability to deliver political advice without regard to the incumbent minister's party affiliation (Christensen, 2006; Christiansen \& Togeby, 2006b). State secretaries and all other civil servants remain at their post when ministers and governments change (White Paper 1537/2013). In sum, the Danish state administration is a pure merit bureaucracy. The only non-merit element is that ministers are allowed to have one or two politically selected advisers. They come and go with the minister, and they do not have administrative responsibilities.

Sweden has taken a much more liberal stand on political advisers, and there are two main differences compared to the Danish model: The state secretaries, who are second in command in the ministries, just below the minister, are officially politically appointed (and resign with the minister) (Ullström, 2011). The other difference is that the total number of political advisers is significantly higher in Sweden than in Denmark. In addition to the state secretaries, ministers are allowed a number of ministerial advisers who give them advice on policy as well as political-tactical advice (Wilson \& Barker, 2003; Niklasson, 2005; Tiernan, 2006; Eichbaum \& Shaw, 2007; 2010). This group includes press secretaries and advisers whose main expertise is the policy field for which the minister is responsible. Altogether, about 200 of the 4600 employees in the Swedish ministries are political advisers (www.government.se). Only the state secretaries of the political advisers are part of the regular organizational hierarchy, i.e. they are political appointees. The other political advisers form an organization within the organization, which means that they have no formal authority over the merit-recruited civil servants (Ullström, 2011). Most of the Swedish advisers have previously worked as policy professionals (79\%). A usual source of recruitment is the political parties and their central organizations (Garsten, Rothstein \& Svallfors 2015). In general the Swedish political advisers have their educational background in economics and political science.

Interestingly, the particular way the two countries organize political advice is motivated by the growing demand of higher quantity and quality of political advice, as well as the intent to protect the neutrality of the civil service (Larsson, 1990; White Paper 1443/2004).

In sum, Denmark and Sweden are similar in most respects, but their organization of political advice differs significantly: Sweden has many and Denmark has few political advisers, and Sweden has politically appointed state secretaries. Although our design is not a 
perfect most similar systems design, we use this difference to study the effects of political advisers on the tasks and task perceptions of civil servants.

Data

Our data come from two web surveys conducted in the summer and autumn of 2012. Before the surveys were sent out, the government administrations were informed about the project, and we conducted eight pilot interviews with former ministers, civil servants, and political advisers in both countries.

The surveys include aspects relating to how civil servants perceive their tasks and how they organize their work. In Sweden, the survey was sent to all civil servants with a university degree, which added up to 1746 respondents. $49 \%$ answered the survey. In Denmark, civil servants in a leading position in the departments, agency directors and special advisers received the questionnaire. The overall response rate was $78 \%$, equalling 368 respondents. ${ }^{1}$ To ensure a fair comparison, this article only uses the figures for respondents with a leading position (Denmark: department managers and office managers and equivalents). This group includes 282 Danish respondents, corresponding to a response rate of $76 \%$. In the Swedish case, the group of civil servants in a leading position (e.g. assistant undersecretaries, experts, deputy assistants, and ambassadors placed in the ministries) includes 393 persons, corresponding to a response rate of $47 \%$.

At the time of the survey, Denmark had a centre-left government consisting of the Social Liberal Party, the Social Democrats and the Socialist People's Party, and Sweden had a centre-right government consisting of the Moderate Party, the Centre Party, the Liberal People's Party and the Christian Democrats. Both countries had minority governments in the period under investigation.

\section{Measures}

We use two additive indexes to measure policy-related matters and political-tactical matters.

Political-tactical tasks are measured using five statements - loading on one dimension in a factor analysis - regarding the extent to which merit-recruited civil servants discuss with their minister how to promote their policies (Cronbach's alpha $=0.82$ ). The questions are: "To what extent do you agree or disagree with the following statements:" 'I give advice on how the minister's policies can best be promoted in 1) the minister's party, 2) the parliament, and 3) the government', 'I give advice on how the minister's long-term policies can be developed', and 'Together with the minister I participate in informal meetings with the minister's party colleagues where the minister's policies are discussed"'. Response options: "Totally agree", "Agree", "Neither agree nor disagree", "Disagree”, “Totally disagree".

Tasks related to policy advice are measured using three statements - loading on one dimension in a factor analysis - about the extent to which a merit-recruited civil servant should be involved in different policy matters (Cronbach's alpha =.62). The questions are: "To what extent, according to you, should the following tasks be part of your job as a civil

\footnotetext{
1. One reason for the very high Danish response rate was that the survey was endorsed by the permanent state secretary of the Danish Prime Minister's office. There was no such endorsement in Sweden.
} 
servant? 'Implement the government's political intentions and decisions', 'Develop basis for decision to the political leadership', and 'Critically examine and give contrasting images to government's intentions and decisions"”. Response options: "To a very large extent", "To a great extent", "To some extent", “To a limited extent", "To a very limited extent".

Two questions measure political reception and role uncertainty: (1) "How difficult or easy is it to know what your department's political leadership wants within your field of activity?" The scale runs from "Very difficult", "Difficult", "Neither", "Easy", "Very easy". (2) "To what extent do you agree or disagree with the following statement? 'I often experience situations where it is unclear what the limits are for rules and norms related to the advising and support I can offer the minister"". The scale runs from "Strongly agree", "Agree", "Neither", "Disagree" and "Strongly disagree". In Table 1 the first question is labelled "Politically Uncertainty", the second question "Role Uncertainty". In our analyses, indexes for political process and policy matters and "Political Uncertainty" together with "Role Uncertainty" run from 0 to 1.

The design of the paper relies on the assumption that Denmark and Sweden are very similar on relevant factors concerning the political system in general and the central administration in particular. Our main independent variable is the country dummy, and we add a number of individual level control variables: gender ( 0 - man, 1 - women), age (eleven categories, from 26-30 years to $>70$ years), seniority ( 21 categories, from $<1$ year to $>20$ years), hierarchical position ${ }^{2}(0$ - lower level executives, 1 - chief executives), and size of department $(0 \text { - smaller departments, } 1 \text { - the five largest departments in terms of personnel })^{3}$. Since the respondents are nested within their departments, they should not be analysed as independent observations. We use multi-level modelling to avoid this problem (Hox 2002). ${ }^{4}$

\section{Analysis}

The descriptive data in Table 1 reveal that Swedish civil servants are slightly more inclined towards policy tasks than their Danish colleagues, but also that Danish civil servants find political-tactical tasks to be a much more natural part of their job than their Swedish colleagues. The countries differ on number of women in leading positions, age, seniority and staff in the large departments. Denmark has fewer women in leading positions, and the Danish respondents are also slightly younger, less senior and fewer of them work in a large department. There are also more chief executives in the Danish data. That is partially explained by the fact that their state secretaries are civil servants and not political appointees as they are in Sweden. To be able to assess the influence of the control variables on the dependent variables, we first report a bivariate regression followed by the full model with control variables.

\footnotetext{
${ }^{2}$ Chief executives in Denmark are defined as permanent state secretaries and vice state secretaries (afdelingschefer). In Sweden they are defined as departmental executives (departementsråd).

${ }^{3}$ The five largest departments in Denmark are the Ministries of Business and Growth, Finance, Foreign Affairs, Justice and Taxation. The five largest departments in Sweden are the Ministries of Finance, Foreign Affairs, Health and Social Affairs, Justice and Enterprise, Energy and Communications.

${ }^{4}$ Two of our dependent variables are on an ordinal scale, but because it is easier to interpret the coefficients, we use XTMIXED in STATA 13.1. When we use the ordinal command, MEOLOGIT, the results are robust.
} 
Table 1. Descriptive data

\begin{tabular}{lccc|ccc|ccc}
\hline & \multicolumn{3}{c|}{ Pooled sample } & \multicolumn{3}{c|}{ Denmark } & \multicolumn{3}{c}{ Sweden } \\
\hline Variable & Range & Mean & Std. & Range & Mean & Std. & Range & Mean & Std. \\
Political process & $0-1$ & .37 & .24 & $0-.95$ & .51 & .20 & $0-1$ & .29 & .22 \\
Policy & $0-1$ & .86 & .14 & $0-1$ & .80 & .15 & $.33-1$ & .90 & .11 \\
Political uncertain & $0-1$ & .61 & .25 & $0-1$ & .65 & .22 & $0-1$ & .58 & .26 \\
Role uncertain & $0-1$ & .25 & .22 & $0-1$ & .21 & .19 & $0-1$ & .28 & .24 \\
Gender & $0-1$ & 0.43 & 0.50 & $0-1$ & 0.34 & 0.48 & $0-1$ & 0.50 & 0.50 \\
Age & $26>70$ & $46-50$ & & $26>70$ & $41-45$ & & $31>71$ & $46-50$ & 0.14 \\
Chief executives & $0-1$ & 0.20 & 0.40 & $0-1$ & 0.27 & 0.44 & $0-1$ & 0.35 \\
Seniority & $0>22$ & 10.30 & 0.19 & $0>22$ & 8.94 & 0.42 & $0-21$ & 11.28 & 0.31 \\
Departments & $0-1$ & .66 & 0.47 & $0-1$ & .46 & .50 & $0-1$ & 0.81 & 3.93 \\
\hline
\end{tabular}

We start by testing the hypothesis on the distribution of policy advice and political-tactical advice (Hypothesis 1), which states that with more political advisers comes less functional politicisation of the merit-recruited civil service. Table 2 shows a significant difference between the administrations, namely that Danish civil servants are more involved in the political process than Swedish civil servants, when we control for individual level factors. The effect is a true country effect and it corresponds to similar differences found at local government level (Mouritzen \& Svara, 2002: 142). We also find significant effects of age, gender, and size of department. Younger civil servants and male civil servants are more inclined to discuss political issues with their minister than older civil servants and female civil servants. The chief executives are - as expected - more involved in political-tactical advice. Civil servants who work in smaller departments are more involved in the political process, probably because there is more political work per employee in small departments. However, there is no interaction effect between country and size of department. The effect of department size is the same in both countries.

The next step is to examine how administrators see their role in relation to policy advice and political-tactical advice conditioned on the degree of functional politicisation. Hypothesis 2 stipulated that functional politicisation to some extent will crowd out part of the orientation towards policy advice. Our prediction is that we should find a higher degree of crowding out in Denmark than in Sweden because of the higher level of functional politicisation in Denmark. The results in Table 2 support our hypothesis. Administrators from Denmark describe themselves significantly less policy oriented as it is measured here.

If we look separately at the extent to which a civil servant should "critically examine and give contrasting images", the difference between the two countries is striking. Even though previous studies have found that individual Danish civil servants emphasize the importance of speaking their minds to the minister and occasionally arguing against her proposals (Bishoff 2012: 110), the general pattern in Denmark is that only $14 \%$ of the civil servants think that this should be a part of their role to a "very large extent". The corresponding figure among Swedish civil servants is $40 \%$.

The difference is still there if we include those who agree to a "rather large extent" in the figures; $52 \%$ (Denmark) versus $80 \%$ (Sweden). In another set of questions our results are 
supported even if the difference between the two countries is less impressive: We asked whether civil servants should "strive to provide independent, honest and upright advice". $45 \%$ of the Swedish civil servants totally agree with the statement, but only $35 \%$ of the Danish civil servants (using the same control variables as Table 2, the results are significant at the .002 level). The result tells us that Danish civil servants are less policy concerned than Swedish civil servants. The control variables in Table 2 are also significant, and the tendency for the control variables is the same. Men, younger civil servants and personnel in smaller departments are more active in the political process and more eager to voice their critical opinions. This time also seniority matters. Civil servants who are more senior are likewise more critical. These categories seem to be more involved in the ongoing work at the departments overall. It is interesting that the highest ranking civil servants are more policy oriented than their subordinates; above, we saw that they are also more involved in politicaltactical advice. For this - relatively small - group, functional politicisation does not appear to crowd out their policy orientation.

Table 2. Civil servants involvement in the political-tactical advice and role perception related to policy advice (OLS-regression)

\begin{tabular}{|c|c|c|c|c|}
\hline & \multicolumn{2}{|c|}{ Political-tactical advice } & \multicolumn{2}{|c|}{ Policy advice } \\
\hline \multirow[t]{2}{*}{ Country (Denmark) } & $0.21 * * *$ & $0.16 * * *$ & $-0.10 * * *$ & $-0.12 * * *$ \\
\hline & $(0.03)$ & $(0.02)$ & $(0.02)$ & $(0.02)$ \\
\hline \multirow[t]{2}{*}{ Sex (women) } & & $-0.03 * *$ & & $-0.03 * * *$ \\
\hline & & $(0.02)$ & & $(0.01)$ \\
\hline \multirow[t]{2}{*}{ Age } & & $-0.02 * * *$ & & $-0.02 * * *$ \\
\hline & & $(0.01)$ & & $(0.01)$ \\
\hline \multirow[t]{2}{*}{ Chiefs executives } & & $0.10 * * *$ & & $0.04 * * *$ \\
\hline & & $(0.02)$ & & $(0.01)$ \\
\hline \multirow[t]{2}{*}{ Seniority } & & 0.01 & & $0.01 * *$ \\
\hline & & $(0.01)$ & & $(0.01)$ \\
\hline \multirow[t]{2}{*}{ Department (large) } & & $-0.11 * * *$ & & $-0.03 * *$ \\
\hline & & $(0.02)$ & & $(0.02)$ \\
\hline \multirow[t]{2}{*}{ Intercept } & $0.31 * * *$ & $0.46^{* * *}$ & $0.91 * * *$ & $1.03 * * *$ \\
\hline & $(0.02)$ & $(0.04)$ & $(0.01)$ & $(0.03)$ \\
\hline \multirow[t]{2}{*}{ Department variance } & 0.06 & 0.03 & 0.04 & 0.03 \\
\hline & $(0.01)$ & $(0.01)$ & $(0.01)$ & $(0.01)$ \\
\hline \multirow[t]{2}{*}{ Sd. Residual } & 0.20 & 0.20 & 0.12 & 0.12 \\
\hline & $(0.01)$ & $(0.01)$ & $(0.01)$ & $(0.01)$ \\
\hline Wald $\mathrm{Chi}^{2}$ & 53.13 & 168.34 & 28.83 & 84.23 \\
\hline Level 1 & 610 & 588 & 653 & 628 \\
\hline Level 2 & 30 & 30 & 30 & 30 \\
\hline
\end{tabular}

Note: The dependent variable for political-tactical advice runs from 0 - "totally disagree" to 1 - "totally agree" and the dependent variable for role perception runs from 0 - "to a very limited extent" to 1 - "a very large extent". Standard errors in parentheses $* p<0.10 * * p<0.05$, *** $p<0.01$

Using the results from Table 1 and Table 2, we predict the different outcomes from the two administrations (using margins command, Stata, with the control variables at their mean). Figure 1 shows that Swedish civil servants see themselves as very engaged in policy advice and much less in political-tactical advice. Moreover, the difference between political-tactical advice and policy advice is much larger for Swedish civil servants than it is for Danish administrators. In fact, the difference between political process and policy matters is almost 
twice as large in Sweden than in Denmark. Figure 1 clearly illustrates that our two first hypotheses cannot be rejected.

Figure 1. Differences between Danish and Swedish civil servants' engagement in policy advice and political-tactical advice (Predicted values)

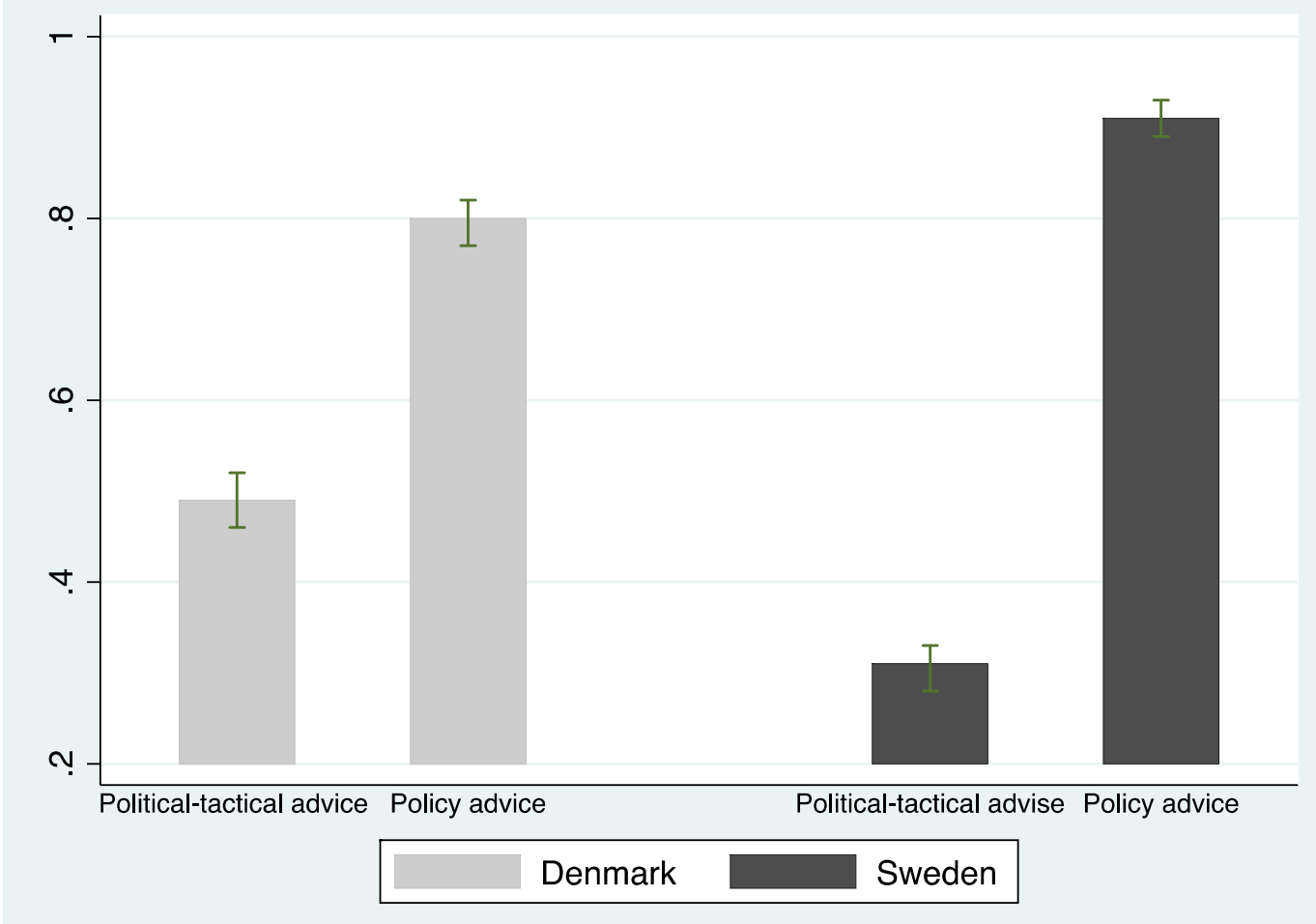

Our interpretation is that partaking in political-tactical advice may to some extent crowd out the orientation towards traditional civil servant tasks such as preparing decisions in order to carry out the minister's and the government's policies, to critically assess the minister's proposals and to work for honest advice. This phenomenon primarily relates to managers below the upper tier. Danish civil servants' comparatively stronger involvement in politicaltactical advice seems to make it harder for them to also be fully engaged in traditional policy advice.

Moving on, we hypothesized that a functional politicisation of the Danish civil service would affect its ability to read the minister's intentions due to the larger involvement of Danish civil servants in political-tactical advice (Hypothesis 3). The column "Political uncertainty" in Table 3 supports this hypothesis. Civil servants in Denmark express a much better understanding of what is going on within the political leadership at their department. The difference between the two countries is robust and significant. If we look at the civil servants' responses, almost one third (30\%) of the Swedish civil servants say it is "very difficult" or "difficult" to know the intentions of the political leadership. It is a striking result that so many Swedish civil servants have a hard time figuring out what the political leadership is aiming at. In Denmark, only $16 \%$ of civil servants have the same problem. Among the control variables, there is only one significant result: Chief executives have fewer problems than other civil servants reading their minister's preferences. 
Hypothesis 4 regarding the clarity of the rules and norms for ministerial advice is not confirmed. Even if Danish civil servants appear to have a better understanding of how their advisery function towards the minister is regulated and how it interferes with their daily job in the bivariate comparison, the difference disappears in our full model. However, the difference between the two countries is almost significant at the lowest level (0.102). Overall, civil servants in both countries are quite certain about the rules of engagement, but also with significant difference between the two countries: close to $90 \%$ of the civil servants in Denmark and slightly over $70 \%$ of the civil servants in Sweden.

As for political uncertainty, the other control variables are not significant. The presence of political advisers makes it somewhat more problematic for civil servants to obtain knowledge about a minister's intention and understanding what kind of advice they can offer a minister. In a system with a clear Weberian ideal model, civil servants' involvement in processes of tactical and policy advice might make them more politically oriented and, ironically, less Weberian in real life. However, involvement in these processes also makes them more certain about their roles and what is expected of them, and thereby perhaps even more effective.

Table 3. Civil servants and political and role uncertainty (OLS-regression)

\begin{tabular}{|c|c|c|c|c|}
\hline & \multicolumn{2}{|c|}{ Political uncertainty } & \multicolumn{2}{|c|}{ Role uncertainty } \\
\hline Country (Denmark) & $\begin{array}{l}0.06 * * \\
(0.02)\end{array}$ & $\begin{array}{l}0.05^{*} \\
(0.03)\end{array}$ & $\begin{array}{l}-0.06 * * \\
(0.02)\end{array}$ & $\begin{array}{l}-0.04 \\
(0.02)\end{array}$ \\
\hline Sex (women) & & $\begin{array}{l}-0.03 \\
(0.02)\end{array}$ & & $\begin{array}{l}-0.02 \\
(0.02)\end{array}$ \\
\hline Age & & $\begin{array}{l}0.01 \\
(0.01)\end{array}$ & & $\begin{array}{l}0.01 \\
(0.01)\end{array}$ \\
\hline Chiefs executives & & $\begin{array}{l}0.07 * * * \\
(0.03)\end{array}$ & & $\begin{array}{l}0.07 * * * \\
(0.02)\end{array}$ \\
\hline Seniority & & $\begin{array}{l}0.00 \\
(0.00)\end{array}$ & & $\begin{array}{c}0.01 \\
(0.01)\end{array}$ \\
\hline Department (large) & & $\begin{array}{l}-0.01 \\
(0.03)\end{array}$ & & $\begin{array}{l}-0.01 \\
(0.02)\end{array}$ \\
\hline Intercept & $\begin{array}{l}0.59 * * * \\
(0.02)\end{array}$ & $\begin{array}{l}0.52 * * * \\
(0.05)\end{array}$ & $\begin{array}{l}0.27 * * * \\
(0.02)\end{array}$ & $\begin{array}{l}0.24 * * * \\
(0.05)\end{array}$ \\
\hline Department variance & $\begin{array}{l}0.03 \\
0.02\end{array}$ & $\begin{array}{c}0.04 \\
(0.02)\end{array}$ & $\begin{array}{l}0.03 \\
(0.01)\end{array}$ & $\begin{array}{l}0.03 \\
(0.01)\end{array}$ \\
\hline Sd. Residual & $\begin{array}{l}0.24 \\
0.01\end{array}$ & $\begin{array}{l}0.24 \\
(0.01)\end{array}$ & $\begin{array}{l}0.22 \\
(0.01)\end{array}$ & $\begin{array}{l}0.22 \\
(0.01)\end{array}$ \\
\hline Wald Chi $^{2}$ & 5.31 & 23.52 & 6.29 & 16.50 \\
\hline Level 1 & 658 & 632 & 614 & 593 \\
\hline Level 2 & 30 & 30 & 30 & 30 \\
\hline
\end{tabular}

Note: The dependent variable for "Easy to understand" runs from 0 "Very hard" to "Very easy". The dependent variable for "Unclear standards" runs from 0 - "totally disagree" to 1 "totally agree". Standard errors in parentheses $* p<0.10 * * p<0.05, * * * p<0.01$.

\section{Conclusions}

Today's political processes are much more demanding than yesterday's. Modern government implies what appears to be steadily increasing regulation of many aspects of human life. Mediatized political processes require ministers to be alert 24/7, and high voter volatility translates into more or less permanent election campaigns. These are some of the 
developments that have increased ministers' demand for political-tactical advice on top of the advice on policy questions which used to be the core of civil servants' services to ministers. In most Western countries, ministers have increased the number of political advisers and deployed them in various ways.

The question is if, how, and to what extent this development has affected the work and role of traditional merit-recruited civil servants. It is difficult to assess these effects because the number of political advisers has increased slowly and because it is difficult to isolate the effects of more political advisers from what is caused by other societal developments. We try to overcome this problem with a most similar system comparison of Denmark and Sweden, which are very similar in many respects, for example a long Weberian tradition for merit recruitment of civil servants. Some 40 years ago they started to drift apart in terms of staffing and organization of political advice. Sweden introduced political appointees and political advisers, which over the years have grown substantially in number, and changed recruitment of the top civil servant - the state secretary - of the ministries from merit to political recruitment. Denmark stuck to merit recruitment and introduced only few political advisers. A comparison of the two countries allows us to assess the effects of different ways of organizing political advice - mainly by assessing the effect of the number of political advisers.

The first thing we show is that Danish civil servants - as measured by managers employed in the ministerial departments - are much more involved in political-tactical advice than their Swedish counterparts. This is not surprising. The demand for political-tactical advice should be of the same magnitude in the two countries, and if Danish ministers have few political advisers to supply such advice, the permanent civil service must deliver it.

The question is if this functional politicisation has affected the classic role of the civil service that is to develop the basis for policies to be decided on by ministers, to critically assess the government's intentions and decisions and to implement policy. We show what we interpret as a crowding out effect of functional politicisation. Danish civil servants are significantly less oriented toward this part of their job.

The existence of many political advisers allows the civil servants to critically assess the government's policies while also concentrating on developing and implementing their minister's decisions and intentions. In comparison, the closeness between minister and civil servants in a system with few political advisers makes the civil servants more reluctant to assess the minister's proposals critically and less occupied with carrying through the minister's policy agenda. We observe that the civil servants become more cautious about "speaking truth to power" and offering critical advice. Functional politicisation thus appears to crowd out the policy advisory function of civil servants to some extent. It should be noted that the crowding out effect is smaller, the higher the hierarchical position of the civil servant. On the other hand, we have also shown that Danish civil servants have less trouble interpreting the wishes and intentions of their minister, and that the rules and norms that regulate their behaviour are less constrained in their daily work. The fusion of the roles as policy adviser and political-tactical adviser that characterizes the Danish civil service seems to have reduced professional competence somewhat, but increased their political responsiveness. 
The crowding out effect found in Denmark is not necessarily (only) an individual phenomenon, but rather one that becomes part of a collective assessment of what a civil servant should focus on. The organization of political advice influences how the work in the central administration is distributed, which in turn affects how civil servants define their job. However it could also be part of the incentive system for civil servants. Since in Denmark there is no "organization within the organization" to take care of political-tactical advice such advice become more important for promotion and career success compared to the Swedish system where such an "organization within the organization" do exist in the form of political appointees and political advisers. This is parallel to Veit and Scholz (2015) who show that "intention signalling" - signalling party political politicisation - is important for German civil servants who work closely with elected politicians.

It is inevitable that top civil servants play some form of political role alongside more neutral administrative functions. They have probably always played a political role, but it has become more prominent with the changes in ministers' environments in recent decades. These political functions may concern ministers' relations to the media, to their own and other political parties, to interest groups, and the possibilities of gathering a parliamentary majority for political ideas. It may further concern policy formation, e.g. deliberations with a minister regarding new policies, and deliberation on administrative implementation (OECD, 2011; Christensen, 2006; White Paper 1354/1998; 1443/2004; 1537/2013). The more meritrecruited civil servants are involved in these tasks, the more the civil service is functionally politicised, and our results indicate that functional politicisation also has implications for the traditional functions of the civil service. The reluctance to supply critical policy advice might be one of them. The consequences of increasingly recruiting policy advisers on political grounds to the central government have only begun to be uncovered. We have uncovered a potential crowding out effect of functional politicisation, but we are so far unable to assess if this also affects the quality of government. So far, our results affect our theoretical understanding of the work of civil servants.

\section{References}

Aberbach, Joel, Robert Putnam, and Bert D. Rockman (1981). Bureaucrats and politicians in Western democracies. Cambridge, MA: Harvard University Press.

Aberbach, Joel \& Bert D. Rockman (1994). Civil servants and policymakers: neutral or responsive competence? Governance, 7, 461-1469.

Bischoff, Carina (2012). Party Patronage in Denmark: The Merit State with Politics 'On the Side'. In Party Patronage and Party Government in European Democracies. Petr Kopecký, Peter Mair, and Maria Spirova (eds.), pp. 93-119.

Christensen, Jørgen Grønnegård (2006). Ministers and mandarins under Danish parliamentarism. International Journal of Public Administration, 29, 997-1019.

Christensen, Jørgen Grønnegård, Robert Klemmensen, \& Niels Opstrup (2014). Politicization and the replacement of top civil servants in Denmark. Governance, 27, 215-241.

Christiansen, Peter Munk, and Lise Togeby (2006a). Power and democracy in Denmark: still a viable democracy. Scandinavian Political Studies, 29, 1-24.

Christiansen, Peter Munk \& Lise Togeby (2006b). Elite transformation in Denmark 19321999. Comparative Social Research, 23, 35-54. 
Dahlström, Carl, Victor Lapuente, \& Jan Teorell (2011). The merit of meritocratization: politics, bureaucracy, and the institutional deterrents of corruption. Political Research Quarterly, 65, 658-670.

Dahlström, Carl (2009). Political appointments in 18 democracies, 1975-2007. QoG Working Paper Series 2009:18. Gothenburg: The Quality of Government Institute.

Damgaard, Erik (2004). Development in Danish parliamentary democracy: accountability, parties and external constraints. Scandinavian Political Studies, 27, 115-131.

Derlien, Hans-Ulrich (2003). Mandarins or managers? The bureaucratic elite in Bonn, 1970 to 1987 and beyond. Governance, 16, 401-428.

de Visscher, Christian, and Heidi Houlberg Salomonsen (2013). Explaining differences in ministerial ménages à trois: multiple bargains in Belgium and Denmark. International Review of Administrative Sciences, 79, 71-90.

Ehn, Peter, Magnus Isberg, Claes Linde, \& Gunnar Wallin (2003). Swedish bureaucracy in an era of change. Governance, 16, 429-458.

Eichbaum, Chris, \& Richard Shaw (2005). Why we should all be nice to ministerial advisers. Policy Quarterly, 1, 18-26.

Eichbaum, Chris, \& Ricard Shaw (2007). Ministerial advisers, politicization and the retreat from Westminster: the case of New Zealand. Public Administration, 85, 609-640.

Eichbaum, Chris, \& Richard Shaw (2008). Revisiting politicization: political advisers and public servants in Westminster systems. Governance, 21, 337-363.

Eichbaum, Chris, \& Richard Shaw (Eds.) (2010). Partisan appointees and public servants: an international analysis of the role of the political adviser. Aldershot: Edward Elgar.

Foster, Christopher D. (2001). The civil service under stress: the fall in civil service power and authority. Public Administration, 79, 725-749.

Gallo, Nick, \& David E. Lewis (2012). The consequences of presidential patronage for federal agency performance. Journal of Public Administration Research and Theory, 22, 219-243.

Garsten, Christina, Bo Rothstein, and Stefan Svallfors (2015). Makt utan mandat. Dialogos Förlag.

Goetz, Klaus H. (1997). Acquiring Political Craft: Training Grounds for Top Officials in the German Core Executive. Public Administration, 74, 753-775.

Hart, Poul 'T., \& Anchrit Wille, A. (2006). Ministers and top officials in the Dutch core executive: Living together. Growing apart? Public Administration, 84, 121-146.

Hox, J. (2002). Multilevel analysis: Techniques and applications. Mahwah, NJ: Erlbaum.

Husted, Turid, \& Heidi Salomonsen (2014). Ensuring political responsiveness: politicization mechanisms in ministerial bureaucracies. International Review of Administrative Sciences, 80, 746-765.

Larsson, U. (1990). Människorna i kanslihuset. In Att styra riket. Regeringskansliet 18401990 (pp. 190-221). Stockholm: Allmänna Förlaget.

Lewis, David E. (2007). Testing Pendleton's premise: Do political appointees make worse bureaucrats? The Journal of Politics, 69, 1073-1088.

Lewis, David E. (2008). The politics of presidential appointments: political control and bureaucratic performance. Princeton: Princeton University Press. 
Lindbom, Anders (1997). Ministern och makten. Hur fungerar ministerstyre i praktiken? Rapport till Förvaltningspolitiska kommissionen. SOU 1997:54. Stockholm: Fritzes Offentliga Publikationer.

Lyngby, Thomas, Søren Mentz, \& Sebastian Olden-Jørgensen (2010). Magt \& pragt. Enevalde 1660-1848. Copenhagen: Gads Forlag.

Maley, Marie (2000). Conceptualising advisers' policy work. The distinctive policy roles of ministerial advisers in the Keating government, 1991-96. Australian Journal of Political Science, 35, 449-470.

Mayntz, Renate, \& Hans-Ulrich Derlien (1989). Party patronage and politicization of the West German administrative elite 1970-1987 - toward hybridization? Governance, 2, 384-404.

Mouritzen, Poul Erik \& James H. Svara (2002). Leadership at the apex: politicians and administrators in Western local governments. Pittsburgh: University of Pittsburgh Press.

Mulgan, Richard (2007). Truth in government and the politicization of public service advice. Public Administration, 85, 569-586.

Mulgan, Richard (2008). How much responsiveness is too much or too little? Australian Journal of Public Administration, 67, 345-356.

Niklasson, Birgitta (2005). Contact capital in political careers. Gender and recruitment of parliamentarians and political appointees. Gothenburg: Dept. of Political Science, University of Gothenburg.

OECD (2011). Ministerial advisors. role, influence and management. Paris: OECD. http://www.oecd-ilibrary.org/governance/ministerial-advisors_9789264124936-en.

Overeem, Patrick (2005). The value of the dichotomy: politics, administration, and the political neutrality of administrators. Administrative Theory \& Praxis, 27, 311-329.

Peters, B. Guy, Rhodes, R. A. W., \& Vincent Wright (Eds.) (2000). Administering the summit: administration of the core executive in developed countries. London: Macmillan.

Peters, B. Guy, \& Pierre, Jon (2004a). Politicization of the civil service: concepts, causes, consequences. In B. Gyu Peters \& Jon Pierre (Eds.), Politicization of the civil service in comparative perspective (pp. 1-13). London: Routledge.

Peters, B. Guy, \& Pierre, Jon (Eds.) (2004b). Politicization of the civil service in comparative perspective. London: Routledge.

Petersson, Olof (2015). Rational Politics: Commissions of Inquiry and the Referral System in Sweden. In Jon Pierre (ed.), The Oxford Handbook of Swedish Politics (pp. 650-662). Oxford: Oxford University Press.

Rothstein, Bo, \& Theorell, Jan (2012). Defining and measuring quality of government. In Søren Holmberg \& Bo Rothstein (Eds.), Good government. The relevance of political science (pp. 13-39). Cheltenham: Edwar Elgar.

Rouban, Luc (2012). Politicization of the civil service. In B. G. Peters \& J. Pierre (Eds.), The SAGE handbook of public administration (pp. 380-391). London: Sage.

Rourke, Francis E. (1992). Responsiveness and neutral competence in American bureaucracy. Public Administration Review, 52, 539-546. 
Schück, Herman (1988). Early Swedish representation: instrument or opponent of the government? Parliaments, Estates and Representation, 8, 23-29.

Silberman, Bernhard S. (1993). Cages of reason: the rise of the rational state in France, Japan, the United States, and Great Britain. Chicago: The University of Chicago Press.

Svara, James D. (1999). Complementarity of politics and administration as a legitimate alternative to the dichotomy model. Administration \& Society, 30, 676-705.

Svara, James D. (2001). The myth of the dichotomy: complementarity of politics and administration in the past and future of public administration. Public Administration Review, 61, 176-183.

Tiernan, Anne-Maree (2006). Advising Howard: interpreting changes in advisory and support structures for the prime minister of Australia. Australian Journal of Political Science, 41, 309-324.

Transparency International (2012). Corruption Perceptions Index 2012. http://www.transparency.org/cpi2012/results

Ullström, Anna (2011). Styrning bakom kulisserna. Regeringskansliets politiska staber och regeringens styrningskapacitet. Stockholm: Dept. of Political Science, Stockholm University.

Veit, Sylvis and Simon Scholz (2015). Linking administrative career patterns and politicization: signalling effects in the careers of top civil servants in Germany. International Review of Administrative Sciences. DOI: 10.1177/0020852314564310

Weber, Max (1958). From Max Weber: essays in sociology. New York: Oxford University Press

White Paper 1443/2004. Betankning nr. 1443 - embedsmaends rådgivning og bistand. Albertsund: Schultz Information. http://www.fm.dk/Publikationer/2004/ /media/Files/Publikationer/2008/Download/Bet aenkning 1443.ashx. With English summary.

White Paper 1354/1998. Betcenkning fra Udvalget om forholdet mellem minister og embedsmaend. http://www.fm.dk/publikationer/1998/betaenkning-nr-1354/

White Paper 1537/2013. Ministrenes sarlige rådgivere. Serviceeftersyn. Government white paper on special advisors. English summary, pp. 179-209.

http://www.fm.dk/publikationer/2013/betaenkning-1537-ministrenes-saerligeraadgivere/

Wilson, Graham, \& Anthony Barker (2003). Bureaucrats and politicians in Britain. Governance, 16, 349-372.

Wilson, Woodrow (1887). The study of administration. Political Science Quarterly, 2, 197222. 